\title{
Impression of Student Knowledge on Decisions Become a Customer of Islamic Banks
}

\author{
Arniati, Muryani Arsal, Akhmad, Asdar, \\ Andi Arifwangsa Adiningrat
}

\begin{abstract}
The purpose of the study is to determine the impression / influence of students' knowledge on the decision to become a customer of Islamic banks. This study uses a quantitative descriptive study with pourposiive samples of 50 VII semester students of the Department of Development Economics, Faculty of Economics and Business, Muhammadiyah University, Makassar. Data collection techniques are observation and questionnaires while data analysis techniques are using simple linear regression analysis. The results showed that students' knowledge had a positive and significant effect on the decision to become a customer of a Sharia Bank.
\end{abstract}

Keywords: Student Knowledge, Decisions, Islamic Banks

DOI : https://doi.org/10.30596/ijbe.v1i2.4284

JEL Classification: M00, M3, M31

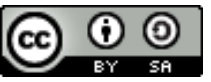

Published by International Journal of Business Economics (IJBE), Indonesia | Copyright (C 2020 by the Author(s) | This is an open access article distributed under the Creative Commons Attribution License http://creativecommons.org/licenses/by/4.0), which permitsunrestricted use, distribution, and reproduction in any medium, provided the original work is properly cited.

Cite this article as:

Arniati, Arsal, M., Akhmad., Asdar., \& Adiningrat, A. A. (2020) Impression of Student Knowledge on Decisions Become a Customer of Islamic Banks. International Journal of Business Economics (IJBE), 1(2), 145-152.

Universitas Muhammadiyah Makassar

Jl. Sultan Alauddin No. 259 Makassar 90221, Indonesia

*Corresponding Author: arniati@unismuh.ac.id 


\section{International Journal of Business Economics (IJBE)}

Vol, 1 Issue 2, pp 145-152, March 2020

http://jurnal.umsu.ac.id/index.php/ijbe

eISSN 2686-472X

\section{INTRODUCTION}

Public knowledge and understanding of Indonesian Islamic banking products and systems is still very limited. This has become a major factor in inhibiting the opportunities for industrial development regarding Islamic banking in Indonesia. This differs from those who prefer conventional banks due to ignorance or lack of understanding of Islamic banks.

Students from the Department of Development Economics at the Faculty of Economics and Bismis have been taught courses related to Islamic banking, so ideally they would prefer Islamic banks to conventional banks. Because they already know and understand, both in general about Islamic banks and the Islamic system, and in particular about the prohibition of the interest system in conventional banks.

Taking into account these factors, the authors are interested in a more in-depth study of the influence of the students of the Department of Development Economics, Faculty of FEB, about how decisions are made to become customers of Islamic banks. Because these students are among the academic people who are expected to promote Islamic banking.

Therefore, it is important to research and know the magnitude of the influence of Islamic Banking knowledge on students in the Development Economics Department, Faculty of FEB, whether students will have accounts at Islamic banks or on average still keep their money in conventional banks. Interestingly, the influence of Islamic banking knowledge needs to be understood.

The reason why this is so interesting is that the Department of Development Economics, Faculty of FEB, University of Muhammadiyah Makassar is an institution that creates intellectual human resources in the field of Islamic banking through an intellectualbased environment (scientific community), with the hope of being able to compete globally.

The Department of Development Economics, Faculty of FEB, is expected to understand the basics of Islamic banking finance, understand the concepts, theories and practices of Islamic banking management and development and research institutions for Islamic finance, especially Islamic banking. Therefore, students of the Development Economics Department who sometimes learn the ins and outs of Islamic banking must choose to become customers or customers of Islamic banks. The decision of students of the Department of Development Economics to become customers of Islamic banks must be well and correctly known.

This is useful to find out the extent to which the courses they receive during lectures influence thinking and thus choose to become customers or customers of conventional banks such as customers who generally become customers of Islamic banks. In addition, the marketing of Islamic banks will increase. This will show that the trust of Islamic banks will be assessed better among the public, especially students.

If public trust in Islamic banks increases in value, then the justice-based Islamic business system will have a great opportunity to be realized immediately. The problem is that although students from the Development Economics Department have received lectures on Islamic banking courses and even participated in Islamic banking practices, so far, there are still students from the Development Economics Department who still save / save at conventional banks, although of course some of them they have realized to become customers of Islamic banks.

Several studies have shown results that support this statement (Arniati, 2016; Arbana, 2016; Bakhit, G. R, et al 2016; Hoq, Mohammad Ziaul et al, 2010; Joko Mariyono, 2013; Muslim Amin, 2013). Several studies have also found that knowledge has 


\section{International Journal of Business Economics (IJBE)}

Vol, 1 Issue 2, pp 145-152, March 2020

http://jurnal.umsu.ac.id/index.php/ijbe

eISSN 2686-472X

a significant effect on the decision to become a customer of Islamic banks, namely Setiawan, (2014); Bodibe Seipati, et al (2016); Farid, (2016); Mariadas, et al (2017); Widhiastuti, (2019); Ergun et al, (2010).

However, apart from student knowledge, there are other factors that are thought to be contextual that influence the decision to become a customer of a sharia bank, namely the support of Hedayatnia (2011); Istiqomah, (2015) Latip, et al (2017); Albashir, 2018. Literature on the decision to become a customer of a sharia bank discusses the existence of contestual factors that shape students to become customers at Islamic banks, including services, marketing strategies.

Therefore, this study aims to test the impression of student knowledge on the decision to become a customer of Islamic banks, so that it is expected to provide empirical input for the development of more concrete student knowledge in order to encourage students to prefer to save in Islamic banks.

The contribution of each of the research journals that have been previously mentioned is in the context of being a material for compiling a start of the art, which is related to a collection of theories, and references either supporting or not supporting research. The several journals that were collected were intended to make the research carried out to be solid, because the content contained in each journal could be used as a reference.

There have been many studies examining the decision to become a customer / customer of Islamic banks, but each place certainly has its own characteristics related to this theme. In addition, the focus of the problems studied is related to the decision to become a customer / customer of Islamic banks which has not been widely implemented by previous researchers. From several journals that have been mentioned, it can be seen that there is nothing specifically discussing the impersion of student knowledge on the decision to become a customer of Islamic banks.

Thus, it can be concluded that the research to be carried out is relatively new and has not been much done by previous researchers.

Student knowledge consists of information already stored in memory. Marketers are very interested in understanding and understanding student knowledge. The information held by students about products or services will greatly influence the purchasing patterns of these students. According to Philip Kotler with the translation of Hendra Teguh, and Ronny A Rusli and Benyamin Molan (2000) states that: "Knowledge is a change in the attitude of an individual that comes from experience." Students have different levels of outcome knowledge, which can be used to interpret new information and make decision choices.

According to Kotler (2000) purchasing decisions are actions taken by consumers to purchase a product. Therefore, consumer decision making is a process of selecting one of several options for solving the problem with a real follow-up. After that consumers can evaluate alternatives and then can determine the attitude taken for the next.

Student decisions arise because of an objective assessment or due to emotional impulses. Decisions in action are derived from a series of activities and mental and emotional stimuli. A complicated decision often involves a number of decisions containing alternatives between two or more options. Decisions often require alternatives between a number of different attitudes. (Nugroho J Setiadi, 2003).

The definition of Islamic banking is included in Law no. 21 of 2008. In the law regarding Islamic banking, it is written: "Sharia banking, namely all matters relating to 


\section{International Journal of Business Economics (IJBE)}

Vol, 1 Issue 2, pp 145-152, March 2020

http://jurnal.umsu.ac.id/index.php/ijbe

eISSN 2686-472X

Sharia Banks and Sharia Business Units, institutional scope, business methods and activities, as well as the processes for conducting their business activities". In avoiding the implementation of banks in the interest system, Muslims introduced the Islamic muamalah principle. Thus, Islamic banking was born to be an alternative alternative solution to the problem of conflicting bank interest among usury. So with this, the longing of Muslims in Indonesia who want to escape from the problem of usury has received the answer to the birth of this Islamic bank.

Based on the literature review above, a research model was developed in the following chart:

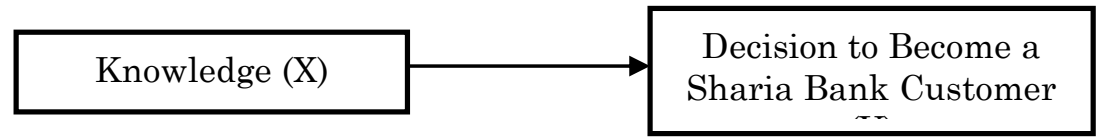

Figure 1. Framework

Based on the framework in the theoretical study mentioned above, a hypothesis is formulated which will be tested in this study. Students' knowledge affects the decision to become customers in Islamic banks.

\section{METHODS}

This type of research is quantitative research, which is located on the campus of the University of Muhammadiyah Makassar, Faculty of Economics and Business, Department of Economic Development, Jalan Sultan Alauddin No. 259 Makassar, with a population of 235 people, namely the whole subject of a study. The research sample consisted of 50 people who were selected by means of a pourposive sample, namely in taking the sample the researcher chose the population based on criteria, namely active students, already sitting in semester VII, having attended lectures on Islamic banking, having active savings.

To collect the data needed in this study is observation, that is, the researcher directly observes the research location to obtain data and information that is appropriate to the problem to be studied. Questionnaire (questionnaire), namely a list of questions distributed or given to respondents.

In this study, the questionnaire was used to obtain data on the influence of student knowledge on the decision to become a customer / customer of Islamic banks using simple linear regression analysis to determine the effect of student knowledge $(X)$ and the decision to become a customer of Islamic banks (Y) with the following mathematical equation: $\mathrm{Y}=\mathrm{a}+\mathrm{bX}$, Where: $\mathrm{Y}=$ Decision; $\mathrm{a}=$ Constant; $\mathrm{X}=$ Student knowledge; $\mathrm{b}=$ regression coefficient

\section{RESULTS AND DISCUSSION}

In this study, the proportion of the respondent's identity is the respondent group according to gender can be seen in the following table: 


\section{International Journal of Business Economics (IJBE)}

Vol, 1 Issue 2, pp 145-152, March 2020

http://jurnal.umsu.ac.id/index.php/ijbe

eISSN 2686-472X

Table 1. Description of Respondents by Gender

\begin{tabular}{lcc}
\hline \multicolumn{1}{c}{ Gender } & Frequency (people) & Persentase (\%) \\
\hline Man & 23 & 46,00 \\
Women & 27 & 54,00 \\
\hline Total respondents & 50 & 100 \\
\hline
\end{tabular}

Table 1, is a description of respondents according to gender which shows that female respondents have a higher proportion of status, up to 27 (54.0\%), while men are up to $23(46.0 \%)$, so it can be concluded that students of the Department of Development Economics in the semester VII is more dominated by women than men.

The description of the respondent's identity is based on the length of time using Islamic banking products, as shown in the following table:

Table 2. Description of Respondents by Length of Use

\begin{tabular}{|c|c|c|}
\hline Long & Frequency (people) & Percentage (\%) \\
\hline$<1$ year & 1 & 2,0 \\
\hline 1 year & 5 & 10,0 \\
\hline 2 years & 16 & 32,0 \\
\hline 3 years & 19 & 38,0 \\
\hline$>3$ years & 9 & 18,0 \\
\hline Total & 50 & 100 \\
\hline
\end{tabular}

According to Table 2, it can be seen that the average time for respondents to use Islamic banking products in the last three years is 19 or $38 \%$, which means that most students who use or choose Islamic banking products are on average 3 years.

Hypothesis testing in this study aims to prove the proposed hypothesis whether the knowledge of Development Economics students regarding Islamic banking has an impact on the decision to become a customer of Islamic banks with the results of simple regression analysis.

Table 3. Analysis Results

\begin{tabular}{lllll}
\hline Factor & $\begin{array}{l}\text { Regression } \\
\text { Coefficient } \\
\text { (b) }\end{array}$ & t-count & t-table & Sig \\
\hline Knowledge & 0,218 & 2,589 & 1,984 & 0,011 \\
Constant $=$ & 3,462 & & & \\
Adjusted $\mathrm{R}^{2}=$ & 0.742 & & & \\
\hline
\end{tabular}

The results of the analysis, namely the knowledge obtained t-count value of 2.589 and t-table 1.984 with a significance level of 0.011 ; because $t$-count $>$ t-table (2.589> $1.984)$, the significance is smaller than $0.05 \quad(0.011<0.05)$, and the regression coefficient has a positive value of 0.218 ; then the hypothesis which states that "student knowledge has a positive and significant impact on the decision to become a customer of Islamic banks" is proven.

\section{Discussion}

The results of this study indicate that students' knowledge of Islamic banking has a positive and significant impact on the decision to become customers of Islamic banks. This research supports the opinion of Apena Hedayatnia (2011), Arniati (2017), Bakhit et al 


\section{International Journal of Business Economics (IJBE)}

Vol, 1 Issue 2, pp 145-152, March 2020

http://jurnal.umsu.ac.id/index.php/ijbe

eISSN 2686-472X

(2016), Dr. Muhamet, (2016), Hoq, Malisah Latip, et al (2017), Istiqomah, YNA (2015), Mohammad Ziaul et al (2010), Joko Mariyono, (2013), Muslim Amin, Zaidi Isa, et al (2013) , Walid Ali Albashir et al (2018) stated that students 'knowledge of Islamic banking is intended to change students' thinking from not understanding Islamic banking to understanding Islamic banking. Thus, students' knowledge about Islamic banks is expected to be able to encourage the intention to make decisions to save in Islamic banks.

The researcher shows the results of his research that students' knowledge of the decision to become a customer of a sharia bank is significant or has a significant effect, this is in line with the results of research by Budi Setiawan (2012) and M. by factors of knowledge, service, product, promotion, place, and distribution. Oriesta Dhea Budi Utamy et al (2019) also found that knowledge, promotion and facilities of Islamic banks have a positive and significant effect on the decision to save at Islamic Banks.

Savings interest can mediate knowledge, promotion, and Islamic banking facilities regarding the decision to save at Islamic Bank. Paul Anthony Mariadas et al (2017), with the results of their research, namely two factors that influence the adoption of Islamic Banking in Malaysia, which are consumer knowledge and customer satisfaction. This shows that the courses they receive during their lectures affect their thinking and thus choose to become customers who generally become customers of Islamic banks. In addition, the marketing of Islamic banks will increase. This will show that the trust of Islamic banks will be assessed better among the public, especially all students. If public trust in Islamic banks increases in value, then the justice-based Islamic business system will have a great opportunity to be realized immediately.

Every student who has knowledge of Islamic banking will influence the decision process to become a customer of an Islamic bank because the stronger the characteristics a person holds, the more difficult it is to change it, or the less influence of knowledge on customers, the smaller the decision to become a customer of Islamic banks. Customers who have insufficient inherent knowledge will easily be influenced by foreign characteristics.

This study is not in line with Ugur Ergun et al (2010) with the results of the study showing that general knowledge about Islamic banking is low. The perception of Islamic banking is not positive. Also the results show that religion is the most influential determining factor in choosing Islamic banking.

\section{CONCLUSION}

Knowledge of Development Economics students on the decision to become customers of Islamic banks has a positive and significant effect. This is evidenced by the regression coefficient of 0.218 , the t-count value is greater than the t-table (2.589>1.984), and a significance value of $(0.011<0.05)$. The influence of student knowledge to become customers of Islamic Bank in the city of Makassar should be further enhanced by means of more effective promotions, for example promotion on social media, socializing differences in interest rates with profit sharing, and improving the quality of service available resources, increasing convenience and availability of facilities. infrastructure, carry out promotional programs more intensively.

The implication of this research is to obtain a formulation that increases in decision making to become customers of Islamic banks by increasing student knowledge on an ongoing basis. The findings of this study reinforce the theories so that students will acquire and develop knowledge, attitudes, values and skills about Islamic banking that are 


\section{International Journal of Business Economics (IJBE)}

Vol, 1 Issue 2, pp 145-152, March 2020

http://jurnal.umsu.ac.id/index.php/ijbe

eISSN 2686-472X

beneficial to social life. The expected results of the research are: a). As a material for scientific information in syariah science, especially in the field of Islamic banking analysis, one of which is in the field of analysis. The influence of knowledge of students of the Development Economics Department on saving at Islamic banks. b). As material for scientific studies to add to the treasures of scientific development at the Muhammadiyah University of Makassar library. c). As information material for further researchers who want to examine the problems of Islamic banking with different aspects.

The research that was carried out was flawed because there were several limitations, including the content, the concept, the focus of the problem and the location of the research and the researcher only used one independent variable and the dependent variable, so with the limitations of these variables it is expected that the next researcher will use more than one independent variable. and using methods other than those used by researchers.

\section{REFERENCE}

Antonio, Syafii, 2001. Dari Teori Ke Praktik Bank syariah, Jakarta: Gema Insani.

Apena Hedayatnia (2011) Bank Selection Criteria in the Iranian Retail Banking Industry. International Journal of Business and Management Vol. 6, No. 12; December 2011 222 ISSN 1833-3850 E-ISSN 1833-8119 Bank Selection Cri

Arbana Sahiti Phdc. Dr. Muhamet, (2016). The Role of Financial Management in Strategy Execution. ELK Asia Facific Journal ISSN 2349-2325 (Online); DOI: 10.16962/EAPJFRM/issn. 2349-2325/2016; Volume 7 Issue 4 (2016)

Arniati, 2016 The Effect of the Entrepreneurial Learning Design on Students' Entrepreneurial Comptence in Vocational High Schools in Makassar http://www.scimagojr.com/journalsearch.php?q=17700155408\&tip=..

Bakhit, G. R1,2 Alamin, M.,A1, (2016). The Role of Financial Management in the Decision-making of Business. IOSR Journal of Business and Management (IOSRJBM) e-ISSN: 2278-487X, p-ISSN: 2319-7668. Volume 18, Issue 6 .Ver. I (Jun. 2016), PP 111-116 www.iosrjournals.org DOI: 10.9790/487X-180601111116 www.iosrjournals.org 111 | Page, Najran University, Saudi Arabia 2 Faculty of

Budi Setiawan, 2012. Faktor-Faktor Yang Mempengaruhi Dosen Dan Karyawan Iain Antasari Banjarmasin Untuk Menjadi Nasabah Di Bank Syariah. http://idr.uin-antasari.ac.id/id/eprint/1767

Burhan Bungin, 2006. Metodologi Penelitian Kuantitatif: Komunikasi, Ekonomi dan Kebijakan Publik serta Ilmu-Ilmu Sosial lainnya, Ed.1, Cet.2, Jakarta: Kencana.

Burhanuddin Susanto, 2001. Hukum Perbankan Syariah Di Indonesia, (Yogyakarta : UUI Perss, cet ke- 1 .

Bodibe Seipati, Chiliya Norman, Chikandiwa Cristopher Tarisavi (2016) The factors affecting customers' decisions adopt Islamic banking. DOI:10.21511/bbs.11(41).2016.05 Corpus ID: 73534785

Ergu, U., \& Djedovic, I. (2010). Islamic Banking with a Closer Look at Bosnia and Herzegovina : Knowledge, Perceptions and Decisive Factors for Choosing Islamic Banking. 8th International Conference on Islamic Economics and Finance Islamic, $1-12$.

Farid, M. Miftah (2016) Pengaruh Pendidikan Terhadap Pola Pikir Mahasiswa IAIN Antasari Banjarmasin Fakultas Syariah dan Ekonomi Islam Tentang Perbankan Syariah. Skripsi, Syariah dan Ekonomi Islam. 


\section{International Journal of Business Economics (IJBE)}

Vol, 1 Issue 2, pp 145-152, March 2020

http://jurnal.umsu.ac.id/index.php/ijbe

eISSN 2686-472X

Hoq, Mohammad Ziaul; Sultana, Nigar; Amin, Muslim (2010), The Effect Of Trust, Customer Satisfaction And Image On Customers' Loyalty In Islamic Banking Sector. South Asian Journal Of Management; New Delhi, 17(1), 70-93.

Istiqomah, Y. N. A. (2015). The Influence Of Marketing Mix (Product, Price, Place, And Promotion) And Service On Customer's Decision Of Using Bsm Saving Products. Global Review Of Islamic Economics And Business, 3(2), 73-98.

IKONOMIKA :Journal of Islamic Economics and Business

Joko Mariyono, (2013). Determinants Of Customers In Selecting Sharia Banking System For Saving In East Java - Indonesia. Journal of Economics, Business, and Accountancy Ventura Volume 16, No. 3, December 2013, pages 457 - 472.

MalisahLatip, M.H. Yahya, Muhammad Junaina, (2017). Factors Influencing Customer's Acceptance of Islamic Banking Products and Services. Volume 2, No 1 (2017) ISSN: 2527-3434 (PRINT) - ISSN: 2527-5143 (ONLINE) Page: 1 - 18 DOI: 10.24042/febi.v2i1.943

Muslim Amin, Zaidi Isa, (2013), Contrasting the drivers of customer satisfaction on image, trust, and loyalty of Muslim and non-Muslim customers in Malaysia. International Journal of Bank Marketing ISSN: 0265-2323

Oriesta Dhea Budi Utamy, Ratieh Widhiastuti (2019), The effect of Sharia bank knowledge, promotion, and facilities on savings decisions at Sharia banks with savings interest as mediation variables. Journal of Islamic Economics, Management, and Business Vol. 1 No. 1 (2019), 1-28; DOI: 10.21580/jiemb.2019.1.1.3986 Journal of Islamic Economics, Management, and Business- Vol. 1 No. 1 (2019) JIEMB| 1

Paul Anthony Mariadas1 \& Uma Murthy (2017), Factors Influencing the Adoption of Islamic Banking in Malaysia, October 2017 International Journal of Business and Management 12(11):187 DOI: 10.5539/ijbm.v12n11p187

Undang-undang Nomor 21 Tahun 2008 Tentang Perbankan Syariah, Jakarta:PT. Bumi Aksara, 2006

Walid Ali Albashir, Yuserrie Zainuddin, Shrikant Krupasindhu Panigrahi (2018). The Acceptance of Islamic Banking Products in Libya: A Theory of Planned Behavior Approach. ISSN: 2146-4138 available at http: www.econjournals.com International Journal of Economics and Financial Issues, 2018, 8(3), 105-111. 